\title{
Sprememba odnosov $v$ zdravstvenem varstvu kot predpogoj za uspeh zdravstvene reforme
}

\author{
UDK: 614.39:614.2 \\ Janko Seljak \\ Fakulteta za upravo \\ janko.seljak@fu.uni-lj.si \\ Andreja Kvas \\ Visoka šola za zdravstvo \\ Andreja.kvas@vsz.uni-lj.si
}

\section{IZVLEČEK}

Uspeh vsake reforme je odvisen od ljudi, ki naj bi jo izvajali. Zdravstveno reformo Ministrstva RS za zdravje naj bi izvajalo preko 38.000 zaposlenih v sistemu zdravstvenega varstva, ki jim zdravstvena reforma posveča razmeroma malo prostora. Prednostno obravnava le zdravnike, ki so tudi glavni avtorji reforme in ki predstavljajo samo $15 \%$ vseh zaposlenih. $V$ članku so predstavljeni razvoj dominantne vloge profesije zdravnikov med zaposlenimi $v$ zdravstvenem varstvu in oblike, $v$ katerih se pojavlja v sodobnih družbah. Dominantna vloga in moč zdravnikov oz. zdravniških organizacij onemogočata vzpostavitev biopsihosocialnega modela zdravja, v katerem naj bi prešel del odgovornosti in pravic pri postopkih zdravljenja tudi na druge poklicne skupine $v$ zdravstvenem varstvu. $Z$ boljšim izkoriščanjem razpoložljivih človeških potencialov bi se povečala uspešnost in učinkovitost celotnega sistema, pacienti bi bili v večji meri deležni celostne obravnave. $V$ okviru zdravstvene reforme je s predlaganim ustanavljanjem večpoklicnih zdravstvenih timov narejen prvi korak k vzpostavitvi biopsihosocialnega modela zdravja; vendar le na deklarativni ravni in - pri sedanjih odnosih - brez možnosti za uspeh. Treba bi bilo usmeriti več sredstev in dejavnosti na področja povečevanja samozavesti in možnosti izobraževanja nezdravniških poklicnih skupin, ki bi v takšnih timih nastopale, ter tudi dopolnilnega izobraževanja zdravnikov na področju organizacije in menedžmenta.

Ključne besede: odnosi, zdravstveno varstvo, zdravniki, medicinske sestre, zdravstvena reforma. 


\section{Uvod}

Po statutu Svetovne zdravstvene organizacije je zdravje definirano kot stanje popolne telesne, duševne in socialne blaginje in dobrega počutja; ni torej zgolj odsotnost bolezni, ampak pozitiven koncept, ki poudarja, da imajo enak pomen socialne, osebnostne in fizične življenjske razmere. Vsak človek ima temeljno pravico, da uživa najvišjo možno raven zdravja ne glede na raso, veroizpoved, politično prepričanje, gospodarske ali socialne razmere. Zdravje naj bi bilo nezamenljiva osebna lastnost vsakega posameznika in s tem ena najpomembnejših sestavin kakovosti njegovega življenja. Z njim se kažejo mnoge druge človekove lastnosti. To je večdimenzionalni koncept in ne stanje, ampak proces. Zdravje je tudi ustavno zajamčena pravica vsakega državljana Republike Slovenije (v 2. členu ustave je Slovenija opredeljena kot pravna in socialna država). Deklarirana socialna narava države zavezuje državne organe, da omogočijo uresničevanje socialnih interesov prebivalstva, med katere sodi tudi zdravstveno varstvo (Bubnov Škoberne, 1998, str. 31). Država je zato dolžna poskrbeti za učinkovit sistem zdravstvenega varstva.

$\checkmark$ sistemu zdravstvenega ${ }^{\mathbf{1}}$ in socialnega varstva je $\vee$ Sloveniji zaposlenih več kot 50.000, neposredno $v$ zdravstveni dejavnosti pa 38.000 ljudi (Statistični letopis RS 2003 - SL-2003). V tem sistemu so v sedanji hierarhiji poklicev prevladujoči izraziti odnosi podrejanja, saj so si zdravniki $v$ zadnjih stoletjih priborili zelo specifičen položaj $\vee$ družbi na splošno in tudi na področju zdravstvenega varstva. $V$ "zdravnikom podrejenih poklicih" so iz procesa odločanja izpuščene celotne poklicne skupine, ki bi lahko s svojim znanjem na posameznih področjih prispevale $k$ boljši zdravstveni oskrbi. Uspešnost in učinkovitost sistema se lahko bistveno poveča z boljšim vključevanjem vseh sodelujočih $v$ vse faze dela oz. z boljšim izkoriščanjem razpoložljivih človeških potencialov. To je možno le z odpravo odnosov podrejanja oz. z uveljavljanjem odnosov sodelovanja v okviru t. i. demokratičnega profesionalizma, ki upošteva prispevek vseh sodelujočih ter omogoča uveljavljanje novih mehanizmov odločanja, načrtovanja in medsebojnega spoštovanja med poklici v zdravstvenem varstvu.

Ministrstvo Republike Slovenije za zdravje (MZ) je v zadnjem obdobju nedvomno naredilo veliko na pomembnih področjih širšega sistema zdravstvenega varstva, nespremenjeno pa je ostalo področje odnosov med poklici v zdravstvu, se pravi neposredno znotraj sistema. Tudi osnutek zdravstvene reforme, predstavljen $\vee$ beli knjigi, se pretežno ukvarja $z$ drugimi problemi (financiranje, privatizacija, pravičnost, dostopnost ipd.) in manj z samimi odnosi med zaposlenimi $v$ zdravstvenem varstvu in odnosi med pacienti in zaposlenimi. Vendar je uspeh na

1 "Zdravstveno varstvo po tem zakonu obsega sistem družbenih, skupinskih in individualnih dejavnosti, ukrepov in storitev za krepitev zdravja, preprečevanje bolezni, zgodnje odkrivanje, pravočasno zdravljenje, nego in rehabilitacijo zbolelih in poškodovanih. Poleg tega zdravstveno varstvo obsega pravice iz zdravstvenega zavarovanja, s katerimi se zagotavlja socialna varnost $\vee$ primeru bolezni, poškodbe, poroda ali smrti (Zakon o zdravstvenem varstvu in zdravstvenem zavarovanju, Uradni list RS, št. 9/92). 
vseh področjih, ki jih prednostno obravnava osnutek zdravstvene reforme, močno odvisen od teh odnosov, predvsem pa ti odnosi bistveno vplivajo na uspeh procesa zdravljenja konkretno in na splošno zdravstveno stanje prebivalstva. To pa je vendarle glavni cilj sistema zdravstvenega varstva. Poklic zdravnika je $\vee$ tem sistemu dominanten in $v$ interesu profesije je, da se hierarhična struktura odnosov ohrani oz. postane še izrazitejša. $\vee$ članku bo predstavljen profesionalizem pri zdravnikih, katerega moč in oblika bistveno vpliva na model zdravja, ki je $\vee$ neki družbi prevladujoč in ki v veliki meri opredeljuje vse druge odnose $v$ okviru sistema zdravstvenega varstva. Zdravniki zasedajo večino vodilnih mest $v$ zdravstvu in so tudi v večini pripravljavci reforme. Zato je za uspeh reforme nujno razumevanje položaja in vloge zdravnikov, ne samo $v$ sistemu zdravstvenega varstva, ampak $v$ družbi kot celoti. Brez védenja o tem, kako so si zdravniki v družbi priborili položaj, ki ga imajo, in kako jim ga je kljub različnim reformam uspelo ohraniti, ni mogoče razumeti ne sistema zdravstvenega varstva, ki je veljal do sedaj, in tudi ne predlaganih sprememb. Odnosov, ki so nastajali desetletja, se naenkrat ne da spremeniti, nedvomno pa bi lahko Ministrstvo za zdravje tudi v okviru reforme bolj poudarilo ta vidik sistema zdravstvenega varstva, ki za povečanje učinkovitosti ne potrebuje večjih posegov na področju financiranja in lastnine.

\section{Viri hierarhičnih odnosov v zdravstvenem varstvu}

Intenziven razvoj, ki je značilen za večino področij, povezanih s spremembami $\checkmark$ tehnologiji, lahko $v$ zadnjih dvesto letih zasledimo tudi $v$ medicini. Na začetku industrijske revolucije sta dva pomembna dejavnika vplivala tudi na organizacijo zdravstvenega varstva: selitev prebivalstva s podeželja $\vee$ mesta in selitev dela iz gospodinjstva ( $v$ domačem domu) $\vee$ tovarno. Industrializacija in urbanizacija sta uničili tradicionalna socialna omrežja, ki so zagotavljala harmonijo in stabilnost. $\mathrm{Na}$ več načinov se je skušalo nadzorovati življenje delavskega razreda (da ne bi izbruhnili nemiri, da bi se obdržal denar, ki so ga delavci zaslužili v okviru tovarne - razna združenja, tudi varčevalna, klubi, zavarovalne sheme ipd.). "Tovarna sama je ponujala model s svojo idejo o zbiranju ljudi na eni fizično povezani lokaciji z namenom ustvarjanja skupnega rezultata. $V$ tem modelu je vsak delavec imel natančno določeno mesto v delitvi dela" (Dingwall, Rafferty, Webster, 1991, str. 26). Regulacija zdravstva je bila samo del teh procesov oz. idej. Konceptualne spremembe $v$ medicini, ki so vodile $k$ reorganizaciji obstoječih bolnišnic in gradnji novih $\vee$ zgodnji viktorijanski dobi, so bile spodbujene $z$ idejami industrijske revolucije (tovarne) in $s$ spremembami $v$ medicinski tehnologiji. Zgodil se je tudi velik preskok iz razmer, ko je bila skrb za zdravje primarno zagotovljena doma, $v$ razmere, ko zanjo skrbijo plačani zdravniki in nastopajo kot ponudniki na množičnih trgih zdravstvenega varstva (Coburn, Willis, 2000, str. 379). 
Seljak, Kvas

Spremembe odnosov v zdravstvenem varstvu

Prej poklic zdravnika ni bil tako dominanten, ker zdravniki niso bili tako suvereni pri svojem delu. A z razvojem medicinskega znanja in z vse boljšimi tehničnimi pripomočki se je učinkovitost njihovega dela močno izboljšala: zdravili so čedalje več bolezni in njihov uspeh je bil čedalje večji. Spremenila se je tudi narava bolezni v sodobnih industrijskih družbah. Do sredine 20. stoletja so se zdravniki posvečali predvsem smrtno nevarnim, akutnim in nalezljivim boleznim (bolezni »revnih «), po letu 1970 pa so glavni vzroki smrti srčne bolezni, maligne tvorbe (raki), žilne poškodbe centralnega živčnega sistema in nesreče (večinoma bolezni, ki so posledice »družbe obilja «). Z rastjo moči poklica zdravnika in položaja medicine v družbi je to področje postalo predmet preučevanja družboslovnih znanosti.

Razmeroma podrobno je proučeval institucijo zdravstvenega varstva $v$ moderni družbi Parsons (cit. v Toš, Malnar, 2002, str. 5). Veliko je prispeval k sociološkemu razumevanju vloge medicine in bolezni v sodobni družbi. Vztrajal je pri tem, da je bolezen družbeni fenomen, na zdravje pa je gledal kot na pomembno družbeno dobrino, ki je bistvena podlaga za dosežke posameznika in za nemoteno delovanje družbe. Bolezen je konceptualiziral kot obliko deviantnosti oz. kot vlogo, v kateri posameznik lahko "pobegne« pred družbenimi obveznostmi. Skoznjo vstopi $v$ vlogo bolnika (sick role), kar mu omogoča tudi nekatere ugodne socialne učinke. $V$ nasprotju z drugimi oblikami odklonskosti (npr. kriminala) ne velja za krivega, če sprejme določena pravila vedenja.

Parsons je postavil medicino kot poglavitno institucijo nadzora deviantnosti v sodobni družbi. Posameznik, ki vstopa v bolezen, se lahko s tem izogne običajnim odgovornostim, ki se od njega pričakujejo, a obenem ima $\vee$ vlogi pacienta določene dolžnosti, zlasti da želi ozdraveti in zato poišče strokovno pomoč. Zdravnik pa je tista družbena instanca, ki sankcionira vstop in izstop iz bolniške vloge. Parsons pravi, da zdravniki določajo, kdo ima pravico do vloge pacienta in kdo ne, koga zdraviti in koga ne, kar jim daje posebno vlogo $v$ družbi, saj imajo pomemben nadzor nad usodo posameznika in tudi nad dodeljevanjem družbenih sredstev (Pahor, 1999, str. 24-26).

Profesionalizem pri zdravnikih ima štiri bistvene lastnosti:

- zahteva celoto sistematičnega in posplošenega znanja, ki ga je možno uporabiti pri različnih problemih. Zdravniki imajo celoto medicinskega znanja, ki ga uporabljajo za diagnosticiranje različnih bolezni;

- vključuje večjo skrb za interese skupnosti kot za lastne interese. Za zdravnike naj bi bila prva skrb zdravljenje pacientov, ne pa dodatno polnjenje svojih žepov;

- vedenje profesionalcev je pod strogim nadzorom etičnega kodeksa, ki ga uveljavljajo in ohranjajo profesionalna združenja. Zdravniki dajo Hipokratovo prisego, ki določa obveznosti in primerno ravnanje $v$ poklicu. Če prekršijo ta kodeks, jih lahko njihovo združenje izloči iz registra in jim prepove opravljati zdravniški poklic; 


\section{Spremembe odnosov v zdravstvenem varstvu}

- tako visoka plačila (ki jih prejemajo profesionalci) kakor ugled (ki ustreza profesionalnemu položaju) so simbol dosežkov. Izražajo veliko spoštovanje profesionalcev in odsevajo vrednost njihovega prispevka družbi. Zdravniki torej tako, da odpravljajo bolezen, ki ogroža družbo s tem, da onemogoča posameznikom opravljanje njihovih običajnih vlog, močno prispevajo $k$ večji učinkovitosti družbe in zato zaslužijo visoko plačilo (Haralambos, Holborn, 1995, str. 66-67).

Profesija zdravnika naj torej pomeni institucionalizacijo altruističnih vrednot, ker so $v$ družbeni delitvi dela zavezane različnim oblikam storitev in družbenega blagostanja; zavezan je torej skupnosti. Za Parsonsa so profesionalne storitve stranki pomembna alternativa racionalnemu egoizmu kapitalističnega trga. Podobno ima tudi Weber profesionalce za ljudi, ki niso motivirani samo z osebnimi in ekonomskimi interesi, ampak jih zavezuje tudi odgovornost. $V$ tem sociološkem okviru je zlasti medicinska profesija tista, ki naj bi služila drugim in kjer naj ne bi bilo neposrednih materialnih nagrad. Tak pogled kritizira Hughes, ki trdi, da tovrstni ideal o neki profesiji proizvede profesija sama. Hughes tudi poudarja materialne in simbolične ugodnosti, ki izhajajo iz profesije (Turner, 1995, str. 129-130).

Drugi so prav tako opazili, da se zdravniška profesija vede drugače, kot so pričakovali. V praksi se je pokazalo (Becker, Hughes, cit. v Colbourn, Willis, 2000, str. 380), da postaja zdravniški poklic popolnoma nekaj drugega kot etično »dosledno samoregulativna profesija «. Pripadniki teorije moči menijo, da je medicina postala izkoriščevalski monopol. Zdravniška profesija je začela upoštevati zgolj svoje interese in skrbeti za svoj čim večji vpliv in dohodke ("elita moči«). Novowebrovi privrženci teorije moči pa vidijo medicino kot enega od mnogih poklicev, ki uporablja strategijo ekskluzivnosti, s katero pridobiva in ohranja tržni monopol.

Zdravniki nadzirajo vsebino medicinskega dela, paciente, druge poklice $v$ zdravstvenem varstvu in tudi okvir, $v$ katerem se zdravstveno varstvo izvaja (politiko zdravstvenega varstva) (Friedson, cit. v Colbourn, Willis, 2000, str. 380). Po mnenju Illicha zdravstvene ustanove celo ogrožajo zdravje. Po njegovem so za zdravje prebivalstva bolj kot zdravstvena oskrba odločini okolje, zlasti prehrana, delovne razmere, bivanje in higiena. Za industrijsko družbo je značilno dolgočasno in monotono delo, pomanjkanje posameznikove svobode pri vodenju lastnega življenja in prisiljeno pridobivanje materialnih dobrin, ki ga navdihuje zmotno prepričanje, da prinašajo srečo in izpolnitev. Te »tegobe« industrijske družbe so krive za bolezni, ki jih doživljajo njeni pripadniki. Zdravniki lahko pri postavljanju diagnoz in zdravljenju te bolezni bolj škodujejo, kot koristijo. S tem ko zase zahtevajo izključno pravico do diagnosticiranja bolezni, zakrivajo njen resnični izvor (Illich, cit. v Haralambos, Holborn, 1995, str. 468). 
Seljak, Kvas

Spremembe odnosov v zdravstvenem varstvu

Naslednja institucija, ki omogoča ohranjanje nadvlade zdravnikov, so njihova združenja. Zmožni so se bili organizirati, preden je država posegla $v$ zdravstvo in postala glavna delodajalka zaposlenih $v$ zdravstvu. Britansko zdravniško združenje (British Medical Association) je bilo ustanovljeno že leta 1832, zakon, sprejet leta 1858, pa je zdravnikom zagotavljal monopol nad zdravniško prakso in podelil njihovi samoupravi pomembne pristojnosti. Z ustanovitvijo profesionalnega društva je zdravnikom uspelo zagotoviti vpliv na trgu delovne sile in nadzor nad njim, tako da lahko maksimirajo nagrade za svoje delo (Haralambos, Holborn, 1995, str. 68).

Po mnenju teoretikov tudi povečevanje birokracije $v$ zdravstvu in administriranja države na profesijo zdravnika nista bistveno vplivala. Larkin meni, da se je moč zdravnikov $v$ zdravstvenem varstvu in družbi kot celoti samo bolj »izkristalizirala«. To pomeni, da je državna regulacija poklicev odnose $\vee$ zdravstvu zgolj formalizirala z zakoni in da ti zakoni jasno izražajo nadzor zdravnikov nad drugimi sodelavci v zdravstvenem varstvu (mišljeni so tudi alternativni in komplementarni zdravilci). Moč se je torej iz neformalnih oblik prelila v formalne (Colbourn, Willis, 2000, str. 383).

Status in moč zdravnikov sta odvisna od njihove sposobnosti vplivati na trg zdravstvenih storitev in dostop do strank (Larson, cit. $\vee$ Turner, 1995, str. 137). Profesionalizacija je proces, s katerim ponudniki storitev (zdravniki) vzpostavljajo trg za svoje strokovno znanje; ta proces vpliva na družbeno neenakost. Profesija ima tri pomembne razsežnosti:

- ima znanje, ki ga je treba interpretirati, da se lahko uporabi. To znanje predpostavlja formalno izobrazbo in vstopne omejitve;

- vzdržuje stranke za svoje storitve;

- profesionalna skupina ohranja in pridobiva privilegije, s katerimi ohranja avtonomijo.

Razmerje med medicinskimi diskurzi in izvajanjem moči v družbi, tj. zavezništvo diskurza, prakse in profesionalnih skupin je preučeval Foucault. Zanj je naša resničnost samo tisto, kar nam naš jezik dovoli, ker ne poznamo resničnosti zunaj jezika (Turner, 1995, str. 10-17). Bolezni potemtakem ne moremo pojmovati kot naravnih pojavov, ki bi se dogajali zunaj jezika, v katerem so opisane. Teoretično opredeliti neko področje torej pomeni, da ga oblikuješ in pridobiš moč nad njim. Bolezen je produkt medicinskega diskurza, ki odseva dominantni način mišljenja v družbi (npr. homoseksualnost je bila včasih obravnavana kot vedenjska motnja, danes pa je zgolj seksualna preferenca).

Foucault meni, da socialna moč zdravnikov izvira iz dejstva, da lahko definirajo resničnost. Po njegovem so zdravniki in policija nadomestili duhovnike kot varuhe družbene resničnosti. Bolnišnice so eden izmed elementov nadzornega aparata, ki zagotavlja red s politiko discipline. Medicina je $v$ tem kontekstu del obsežnega sistema moralne regulacije ljudi in eden izmed vidikov splošnega "nadzora teles" (Turner, 1995, str. 10-13). 
Moč zdravnikov je produkt in izraz uspele profesionalizacije in je kot primer zanimiva za pogoje nastajanja subpolitične oblikovalne moči profesij (Beck, 2001, str. 311). Bistvena prednost uspešnih poklicnih skupin naj bi bila uspešna praktična aplikacija z raziskovalnim delom pridobljenih spoznanj in izoblikovanih kompetenc $\checkmark$ profesionalnih nadzornih organizacijah. Ko neka poklicna skupina razpolaga $z$ "organizacijsko streho", pod katero so tesno sklenjeni raziskovanje, izobraževanje in praksa, lahko vsebinsko usmerja svojo moč brez zunanjega soglasja. Ta "profesionalni krog moči« je klinika. Večina drugih poklicnih skupin nima inovacijskega vira raziskovanja ali je načeloma odrezana od aplikacije rezultatov svojega raziskovanja oz. jih mora uporabljati pod profesiji tujimi, podjetniškimi merili. Samo medicina $v$ podobi klinike ima organizacijsko ureditev, $v$ kateri je mogoče $z$ neposrednim samorazpolaganjem izvajati in izpopolnjevati razvoj in aplikacijo raziskovalnih rezultatov na pacientu $v$ profesionalni režiji, po lastnih merilih in pod zaščito pred zunanjimi vprašanji in nazori.

Tako nastaja popolno neravnotežje med zunanjimi diskusijami in kontrolami ter interno močjo medicinske prakse. Javnost in politika sta po svojem položaju vedno in nujno neinformirani in brezupno capljata za razvojem na področju medicine. Najpomembneje pa je, da vedno govorita o irealnem, o še ne predvidljivem. Neposredni aplikaciji medicinske prakse na živem subjektu stojita nasproti bojazen in ugibanje o pravnih in družbenih posledicah. Preneseno na politiko: obravnava zakonov sledi po njihovi uveljavitvi, šele takrat je mogoče videti njihove posledice. Javne kritike in debate o tem, kaj raziskovalec sme in česa ne, lahko $v$ okviru klinik že od nekdaj odpravijo s politiko postavljanja pred dejstvo. In celo sodstvo mora tam, kjer se mora odločati o "zdravniških napakah «, posegati po medicinsko določenih in kontroliranih normah in stanjih stvari, o katerih lahko po njihovi družbeni konstrukciji racionalnosti presojajo samo še zdravniki in nihče drug (Beck, 2001, str. 309-312).

Giddens (1997, str. 123) je moč zdravnikov opredelil v kontekstu modernih zdravstvenih sistemov, ki imajo naslednje značilnosti:

- vpeljava znanosti $v$ medicino, ki je povzročila tudi, da je izobraževanje zdravnikov dolgo in sistematično. S tem je bilo izključeno "samoizobraževanje»;

- opredelitev bolnišnic kot prostorov, kjer se zdravijo hujše bolezni. Bolnišnice so namreč dajale prostor, kjer so lahko zdravniki zdravili in preučevali veliko bolnikov $v$ razmerah, ki so omogočale koncentracijo medicinske tehnologije;

- razvoj zdravniške profesije, ki ima jasno prepoznavna etična pravila in veliko družbeno moč. Družbena moč naj bi bila možnost, da stvari spremenimo, postavimo drugače, kot bi bile sicer. To moč lahko ljudje uporabijo tudi za uveljavljanje moči nad drugimi ljudmi, ki jih tako omejimo in zmanjšujemo njihovo svobodo (Haralambos, Holborn, 1995, str. 913). $S$ to družbeno močjo lahko zdravniki omejujejo svobodo vsem drugim poklicem $v$ zdravstvu. 
Seljak, Kvas

Spremembe odnosov v zdravstvenem varstvu

\section{Različni modeli zdravja in odnosi med zaposlenimi v zdravstvenem varstvu}

Pojmovanja o zdravju in bolezni se spreminjajo $v$ skladu $s$ spreminjanjem vodilnih ideologij, vrednostnih sistemov, kulturnih tradicij. Splošne teorije zdravja in bolezni so se organizirale okrog dominantnih ideologij in verovanj neke kulture. $\checkmark$ zgodovini sta se razvila dva temeljna modela pojmovanja problemov zdravja: biomedicinski in biopsihosocialni ${ }^{2}$ model. Biomedicinski bolezenski pojav zožuje na raven celice oz. kemijskega dogajanja. Bolezen obravnava kot posledico motnje $\checkmark$ delovanju človeškega telesa, ki je razumljeno kot biokemijski stroj. Redukcionistično predpostavlja, da so vse človeške motnje povezane s specifičnimi biokemijskimi vzroki v organizmu (celo nekatere duševne bolezni se lahko razložijo v smislu biokemijskih sprememb). Ta model izključuje vse druge vplive, tudi socialne, psihološke in vedenjske razsežnosti človekovega telesnega blagostanja in dobrega počutja. Ker $\vee$ njegovem kontekstu niso smiselni, jih ignorira ali zavestno pušča ob strani. To je model linearnega, vzročno-posledičnega gledanja na bolezen. G. L. Engel (cit. v Rakovec Felser, 2002, str. 19) navaja, da je biomedicinski model predvsem model bolezni in ne zdravja, to pomeni, da je $\vee$ celoti usmerjen $\vee$ razlage nastajanja bolezni, okoliščine, ki vzdržujejo in krepijo zdravje, pa ga ne zanimajo. Je zastarel, saj je pretirano specializiran in zanemarja preventivne dejavnosti.

Biopsihosocialni model zdravja temelji na splošni teoriji sistemov (po Sheridan, Radmacher, 1992, cit. v Selič, 1994, str. 152) in ni zanikanje, temveč razširitev prejšnjega modela. Poudarja skupen pomen (in seveda tudi medsebojno vplivanje) bioloških, psiholoških, kulturoloških in socialnih dejavnikov. Zdravstveno stanje je po mnenju Rakovec Fleserjeve (2002, str. 20) rezultat interakcij makronivojskih (npr. depresije) in mikronivojskih (okvare $v$ celicah, kemijsko neravnotežje) procesov. Povedano drugače, zdravje in bolezen sta multifaktorsko določeni stanji in imata vsako zase številne in različne učinke na človeka. Telesnih in psihičnih pojavov ni mogoče obravnavati ločeno, saj vzajemno vplivajo na posameznikovo zdravstveno stanje. Ta pristop obravnava koncepte medicinske znanosti kot produkt kulturnih sprememb in zanika delitev na duha in telo. Po tem modelu bolezen ne more imeti preprostega vzročnega okvira in ne more biti razumljena zunaj zgodovinskega, socialnega in kulturnega konteksta bolnega človeka.

Biopsihosocialni model zdravja vključuje širok zbir različnih dejavnikov (medsebojno vplivanje bioloških, psiholoških, kulturoloških in socialnih dejavnikov), ki jih ne more obvladati samo ena poklicna skupina (zdravniki), zato ostane $\vee$ tem

2 Nastran Uletova (2003, str. 73) navaja, da zunaj biomedicine obstajajo trije modeli, ki obravnavajo bolezen: psihološki, sociološko-družbeni in kulturološko-antropološki. Psihološki se ukvarja z odnosom med boleznijo in posameznikom oz. s človekovim vedenjem v kontekstu zdravja in bolezni, sociološki razširja pomen in kontekst bolezni na analizo družbenih kazalcev zdravja in bolezni, kulturološki še razširja kontekst bolezni na analizo kulturnih vzrokov bolezni; pri tem je kultura definirana kot kompleks praks, pravil, pomenov in vrednosti, ki so skupni ljudem v neki družbeni skupini in družbi. 
modelu veliko možnosti za delovanje tudi drugim. Pri odkrivanju težav pacientov morajo sodelovati različni strokovnjaki, saj bodo le tako njihove ugotovitve ustreznejše. Ta model torej poudarja pomen obeh, zdravja in bolezni, ne le bolezni, zdravje pa dobiva poseben pomen. Zdravje ni več nekaj samo po sebi danega, temveč dinamičen proces, ki je močno odvisen od izpolnjenosti posameznikovih bioloških, socialnih in psiholoških potreb, za kar se lahko vsakdo aktivno zavzame, zlasti če se nauči prisluhniti sebi. Biopsihosocialni model eksplicitno poudarja odnose tako med pacientom in zdravstvenimi delavci kakor tudi med zdravstvenimi delavci. Če so ti dobri, zdravljenje poteka hitreje in učinkoviteje, krepi pa se tudi pacientovo zaupanje $v$ ustanovo, kjer se zdravi.

\section{Razprava}

$\checkmark$ zadnjih petnajstih letih se je primerjalni položaj zdravnikov $\vee$ Sloveniji močno izboljšal. Podrobnejša obravnava te tematike presega obseg članka, zato bodo navedeni zgolj podatki o povečanju plač zdravnikov. $V$ tabeli 1 so navedena razmerja med plačami posameznih izobrazbenih skupin $v$ dejavnosti zdravstvo in socialno varstvo. Vidimo lahko, da je plača višje medicinske sestre leta 1988 znašala 72 \% povprečne plače zdravnika, leta 2000 pa le še $50 \%$. Podobno je tudi pri zdravstvenih tehnikih oz. srednjih medicinskih sestrah: njihova povprečna plača je padla s 57 \% povprečne zdravnikove leta 1988 na samo 38 \% leta 2000. $\checkmark$ opazovanem obdobju so se razmerja med plačami delavcev $\vee$ zdravstvenem varstvu močno spremenila in dohodkovni položaj zdravnikov se je $v$ primerjavi z drugimi poklicnimi skupinami močno izboljšal. Primerjali smo torej plače predstavnikov poklicev $v$ zdravstvenem varstvu, ki vsi skrbijo za interese skupnosti in so zavezani strogim etičnim kodeksom.

Tabela 1: Indeksi povprečnih mesečnih bruto plač zaposlenih oseb v družbah, podjetjih in organizacijah v dejavnosti zdravstvo, socialno varstvo v letih 1988, 1994 in 2000 po stopnji strokovne usposobljenosti

\begin{tabular}{|l|c|c|c|}
\hline \multirow{2}{*}{ leto } & \multicolumn{3}{|c|}{ stopnja strokovne usposobljenosti } \\
\cline { 2 - 4 } & $\begin{array}{c}\text { visoka } \\
\text { (zdravniki) }\end{array}$ & $\begin{array}{c}\text { višja } \\
\text { (višje medicinske sestre) }\end{array}$ & $\begin{array}{c}\text { srednja } \\
\text { (srednje medicinske sestre) }\end{array}$ \\
\hline 1988 & $100 \%$ & $72 \%$ & $57 \%$ \\
\hline 1994 & $100 \%$ & $57 \%$ & $44 \%$ \\
\hline 2000 & $100 \%$ & $50 \%$ & $38 \%$ \\
\hline
\end{tabular}

Vir: SL-1991, str. 461-63, SL-1996, str. 228-30, SL-2002, str. 257-60.

$3 \mathrm{~V}$ skupini zaposlenih z visoko izobrazbo je več kot tri četrtine zdravnikov in zobozdravnikov, v drugih dveh skupinah pa so najštevilnejše (tudi več kot tri četrtine) medicinske sestre oz. zdravstveni tehniki. 
Poklic zdravnika ima $v$ Sloveniji nedvomno večino lastnosti, ki jo teoretiki pripisujejo profesijam (glej poglavje 2). $\vee$ začetku zdravstvene reforme so bile jasno vidne težnje, da bi zdravnike omejili pri kopičenju privilegijev in dali možnost večjega vpliva tudi drugim poklicnim skupinam $\vee$ zdravstvenem varstvu. Vendar se je tudi v Sloveniji pokazalo, da bo država zgolj formalizirala "nadzor zdravnikov nad drugimi sodelavci v zdravstvenem varstvu«. Tako za zdravstveni sistem, še bolj pa za državljane, bi bilo koristno, da bi bil ta nadzor čim manjši. V Sloveniji so bila zdravniška združenja $\vee$ zadnjem desetletju nedvomno uspešna pri borbi za privilegije svojih članov. $\vee$ razvitih državah se je pridobivanje teh privilegijev odvijalo nekaj desetletij prej in so se trendi v zadnjih letih nekoliko obrnili (teorija o "proletarizaciji medicine" temelji na teh trendih: npr. Turner, 1995, Colbourn, Willis, 2000). V Sloveniji bi lahko $v$ okviru zdravstvene reforme zdravniški profesiji postavili realne okvire na ravni razvoja naše družbe in s tem dali možnost drugim poklicnim skupinam $v$ zdravstvenem varstvu, da s svojim znanjem na področjih, ki znanje zdravnikov dopolnjujejo, bistveno bolj prispevajo k višjemu nivoju zdravstvenega varstva $\vee$ Sloveniji.

Poglejmo si, kaj o tem pravijo avtorji osnutka zdravstvene reforme. "Potrebno bo raziskati spreminjajoče se vloge posameznih delavcev $v$ zdravstvenem timu in jim te vloge priznati. To bo zahtevalo premagovanje zaprtosti in sebičnosti posameznih poklicev in prenašanje nekaterih tradicionalnih odgovornosti na druge poklice. Zlasti bo $\vee$ prihodnosti taka omejena prerazdelitev potekala $\vee$ smeri od zdravnikov k medicinskim sestram ( $M Z, 2003$, str. 151). "Spremembe bodo tudi na področju pridobivanja novih veščin in izboljšanih načinov komuniciranja med samimi zdravstvenimi strokovnjaki in med zdravstvenimi strokovnjaki in pacienti. Dodiplomsko izobraževanje za področje kakovosti bo moralo bolj poudariti učenje na podlagi z izsledki podprte medicine in timskega, večpoklicnega in multidisciplinarnega ${ }^{\mathbf{4}}$ dela, kar bo naloga vseh šol, ki izobražujejo zdravstvene strokovnjake." (MZ, 2003, str. 171).

Kako naj bi te vizije udejanjali $\vee$ praksi? Že sam pregled avtorjev osnutka zdravstvene reforme kaže na ogromno moč, ki jo imajo na tem področju zdravniki - od zdravstvenih delavcev so med njenimi avtorji navedeni samo zdravniki: ni medicinskih sester, ni farmacevtov ali drugih nezdravniških poklicnih skupin. Pri sedanji miselnosti in moči, ki jo imajo zdravniki, je ideja o enakopravnih večpoklicnih timih $v$ zdravstvu čista iluzija. Torej tudi sami avtorji niso bili pripravljeni "premagati zaprtosti in sebičnosti « zdravniškega poklica in prenesti del tradicionalnih odgovornosti na druge poklice.

4 Večpoklicni tim sestavljajo strokovnjaki različnih poklicev (npr. zdravnik specialist ortoped, farmacevt, medicinska sestra, zdravstveni tehnik, fizioterapevt, socialni delavec). Multidisciplinarni tim sestavljajo poklici različnih strokovnih disciplin, npr. zdravnik specialist nevrolog, zdravnik specialist nevrokirurg, zdravnik specialist internist. Timi so lahko obenem večpoklicni in multidisciplinarni. 
Tudi v primeru, da bodo večpoklicni timi oblikovani, bo vodja nedvomno zdravnik. Glede na njegovo strokovno znanje na področju zdravja je to edino pravilno. Vendar ali ima dovolj znanja na področju vodenja tima oz. področja organizacije in menedžmenta? Trenutni sistem izobraževanja zdravnikov za biomedicinski model zdravja spodbuja avtoritativne odnose $v$ zdravstvu. Avtorji bele knjige ponujajo zgolj izobraževanje zdravstvenih menedžerjev za kakovost (MZ, 2003, str. 171), kar je premalo. $\checkmark$ zdravstvenem timu bo vsak zdravnik menedžer, zato je treba vnesti več predmetov z organizacijskega področja $v$ predmetnik medicinskih fakultet. Trenutno zdravniki pri vodenju procesa zdravljenja uporabljajo metode, ki so značilne za procese z razmeroma nizko kvalificirano delovno silo: uveljavljanje reda in discipline z jasno opredeljeno hierarhijo poklicev na osnovi izkušenj iz začetka in sredine prejšnjega stoletja. $\vee$ prehodu $\vee$ postmoderno je treba oblikovati zdravstveni tim visoko izobraženih delavcev različnih poklicev ter jih motivirati in spodbujati $k$ ustvarjalnosti. $V$ današnjem času je to tim, sestavljen iz strokovnjakov z zdravniški primerljivo izobrazbo in znanjem na področju svojega poklica. Za uspešno vodenje tovrstnega tima, ki bi prispevalo k uspešnejšemu zdravljenju, pa je potrebno znanje, ki ga zdravniki danes nimajo.

Kako spremeniti nadvlado zdravnikov $\vee$ sistemu zdravstvenega varstva $\vee$ obliko, ki bo pri procesu zdravljenja upoštevala tudi mnenje predstavnikov drugih poklicnih področij? V osnutku zdravstvene reforme je s predlogom ustanavljanja večpoklicnih timov narejen prvi korak. Drugi korak je, da se poveča samozavest nezdravniških poklicnih skupin, ki bodo znotraj teh timov nastopale. Medicinske sestre imajo $v$ tem procesu nedvomno osrednjo vlogo, saj so znotraj zdravstvenega varstva največja poklicna skupina (več kot 14.500 zaposlenih). Poklic medicinske sestre je zgodovinsko in vsebinsko ter še posebno spolno zaznamovan s podrejenostjo zdravniškemu poklicu (Kvas, 2003). Priznanje dejavnosti zdravstvene nege kot pomembnega dela procesa zdravljenja in $s$ tem priznanje nosilk zdravstvene nege kot enakopravnih članic zdravstvenega tima bi bil lahko eden od pomembnih korakov $k$ drugačnemu pojmovanju zdravja in zdravljenja. $V$ zdravstvenem timu je nujno enakomerneje porazdeliti dolžnosti, odgovornosti in tudi pravice med predstavniki različnih poklicnih skupin. Za to je nujno oblikovati močno poklicno skupino medicinskih sester, ki bo s svojim znanjem na področju zdravstvene nege lahko uveljavljala svoj prispevek k zdravju pacientov. Raziskave kažejo (Kvas, 2003; Klemenc, Pahor 2001), da to lahko naredijo le izobražene, samozavestne medicinske sestre, ki upoštevajo profesionalna etična načela. Potrebno je uvesti izobraževalni sistem medicinskih sester, ki bo primerljiv z zdravniškim: pospešiti uvajanje univerzitetnega študija, čimprej začeti s pripravo podiplomskih in doktorskih študijev na področju zdravstvene nege. Medicinske sestre sedaj nimajo možnosti univerzitetnega in podiplomskega študija v svojem poklicu. Šolanje nadaljujejo na drugih smereh (predvsem na področju organizacije, pedagogike, andragogike in drugih družbenih ved), kar pogosto pomeni, da na teh področjih nadaljujejo tudi svojo poklicno pot. S tem se iz zdravstvene nege in posledično tudi 
iz zdravstvenega varstva kot celote izgublja velik potencial, saj iz njega odhajajo prav tiste, ki bi s svojim strokovnim, pedagoškim in raziskovalnim delom lahko največ prispevale $k$ izboljšanju razmer. Odhajajo torej tiste medicinske sestre, ki bi lahko bile nosilke sprememb, zdravstvena nega se tako ne more uveljaviti kot enakovredna $v$ procesu zdravljenja in zdravniki lahko ohranjajo svoj dominantni položaj.

\section{Zaključek}

Dominantna vloga zdravniškega poklica med poklici v zdravstvenem varstvu je nedvomno zgodovinsko pogojena. Vodenje zdravstvenega procesa na osnovi hierarhične strukture je rezultat preteklih razmer, ki bi se tudi v zdravstvu moralo umakniti modernejšim oblikam vodenja tima enakopravnih poklicev. Zdravstvena reforma temu področju posveča razmeroma malo prostora in še to $v$ glavnem na deklarativni ravni. Enakopravnejše odnose med poklici v zdravstvenem varstvu, ki bodo imeli za posledico tudi enakopravnejši odnos zdravstvenih delavcev do pacientov je možno uvesti le v okviru biopsihosocialnega modela zdravja.

Moč zdravnikov izhaja iz značilnosti njihovega dela in področja, na katerem to delo opravljajo. Tudi osnove za spremembe je treba iskati tam. Moč zdravnikov se lahko zmanjša le tako, da se prerazporedi njihova trenutna odgovornost pri zdravljenju ljudi. V okviru biomedicinskega modela, kjer se preučevanje bolezni omeji na kemijsko dogajanje $v$ telesu, ima absolutno oblast samo tisti, ki ta dogajanja pozna (zdravnik) in pri tem modelu enakopravni odnosi med poklici $\vee$ zdravstvu niso možni. V okviru biopsihosocialnega modela, ki vključuje veliko širši zbir različnih dejavnikov, ki jih ne more obvladati samo ena poklicna skupina, pa je veliko prostora še za druge poklicne skupine $v$ zdravstvu (tudi komplementarne in alternativne poglede). $\vee$ smislu osnutka zdravstvene reforme se morajo "določene tradicionalne odgovornosti prenašati na druge poklice«. Čim hitreje se bo ta proces začel in na čim več področjih bo potekal, prej se bo zmanjšal tudi pritisk zdravnikov na povečevanje privilegijev in izboljševanje relativnega položaja med poklicnimi skupinami $v$ zdravstvu in izven zdravstva.

Boj visokoprofesionalnih skupin (zdravniki so samo najizrazitejši primer, so pa tudi še druge: sodniki, visokošolski profesorji ipd.) za čim boljši družbeni položaj vseskozi poteka. Od spretnosti države je odvisno, kako bo ta boj upravljala.

$\checkmark$ Sloveniji je $\vee$ preteklem desetletju prišlo med zdravniškimi organizacijami in državo do več sporov. Iz večine so prišle zdravniške organizacije kot zmagovalci. Država je skušala omejiti privilegije zdravnikov in zaradi velike družbene moči, ki so jo organizacije zdravnikov takrat že imele, ji to ni uspelo. Zato je treba ukrepe "od zgoraj navzdol« kombinirati z vzpostavljanjem ravnovesja profesionalnih skupin zdravnikov z drugimi in $s$ tem z zmanjševanjem njihove relativne moči. Ta proces mora potekati tudi od spodaj navzgor in cilj se lahko doseže le z enakomernejšo 
porazdelitvijo moči v zdravstvenem timu. Tudi drugi zdravstveni delavci (medicinske sestre, delovni terapevti, radiološki inženirji, fizioterapevti, farmacevti idr.) so strokovnjaki na svojih področjih in zdravstvena oskrba prebivalstva se lahko bistveno izboljša, če se bo pri procesu zdravljenja upoštevalo tudi njihovo strokovno znanje. Zdravstvena reforma Ministrstva RS za zdravje bi lahko bila priložnost, da bi te procese pospešili.

\section{Literatura in viri}

- Beck, U. (2001): Družba tveganja. Na poti v neko drugo moderno, Knjižna zbirka Temeljna dela, Ljubljana.

- Bubnov Škoberne, A. (1998): Pravno-organizacijski vidiki zdravstvenega varstva. V: Polajnar Pavčnik, A., Wedam Lukič, D. Pravo in medicina. Ljubljana: Cankarjeva založba, 17-39.

- Coburn, D., Willis, E. (2000): The Medical Profession: Knowledge, Power, and Autonomy. V: Albrecht, G. L.; Fitzpatric, R., Scrimshaw, S. C. (ur). Social Studies in Health \& Medicine. London: Sage, 377-93.

- Dingwall, R., Rafferty, A., Webster, C. (1991): An Introduction of the Social History of Nursing, Routledge, Ljubljana.

- Giddens, A. (1997): Sociology (third edition), Polity Press, London.

- Haralambos, M., Holborn, M. (1995): Sociologija: teme in pogled, Državna založba Slovenije, Ljubljana.

- Klemenc, D., Pahor, M. (ur.) (2001): Medicinske sestre v Sloveniji, Društvo medicinskih sester in zdravstvenih tehnikov Ljubljana, Ljubljana.

- Kvas, A. (2003): Razlike v odnosu do izobraževanja in zdravja, vrednot, etike in samopodobe medicinskih sester $v$ Sloveniji, magistrsko delo. Fakulteta za družbene vede, Ljubljana.

- Ministrstvo za zdravje RS (2003): Zdravstvena reforma (osnutek), Ministrstvo za zdravje RS, Ljubljana.

- Nastran Ule, M. (2003): Spregledana razmerja: o družbenih vidikih sodobne medicine, Aristej, Ljubljana.

- Pahor, M. (1999): Sociologija za zdravstvene delavce, Univerza v Ljubljani: Visoka šola za zdravstvo, Ljubljana.

- Rakovec Felser, Z. (2002): Zdravstvena psihologija, Univerza v Mariboru: Visoka zdravstvena šola, 19-22.

- Selič, P. (1994). Biopsihosocialni model zdravja. Anthropos 26 (4-6), 150-69.

- Toš, N., Malnar, B. (2002): Družbeni vidiki zdravja. Sociološka raziskovanja odnosa do zdravja, Fakulteta za družbene vede: Center za raziskovanje javnega mnenja in množičnih komunikacij, Ljubljana.

- Turner, B. S. (1995): Medical power and social knowledge (second edition), Sage Publications, London.

- Zakon o zdravstvenem varstvu in zdravstvenem zavarovanju, Uradni list RS, št.9/92

- Zavod RS za statistiko (1991): Statistični letopis RS 1991, Zavod RS za statistiko, Ljubljana.

- Zavod RS za statistiko (1996): Statistični letopis RS 1996, Zavod RS za statistiko, Ljubljana.

- Zavod RS za statistiko (2002): Statistični letopis RS 2002, Zavod RS za statistiko, Ljubljana.

- Zavod RS za statistiko (2003): Statistični letopis RS 2003, Zavod RS za statistiko, Ljubljana. 


\section{Seljak, Kvas}

Spremembe odnosov v zdravstvenem varstvu

Janko Seljak je doktor ekonomskih znanosti. Je sodelavec za področje statistike na Fakulteti za upravo Univerze v Ljubljani. Aktivno je sodeloval pri projektih s področja uravnoteženega regionalnega in strukturnega razvoja, varstva okolja, zaposlenosti v javnem sektorju, ekonomike javnega sektorja, davkov, merjenja kakovosti pedagoškega dela ter ekonomike in odnosov $v$ zdravstvu.

Andreja Kvas je magistrica sociologije. Najprej je bila zaposlena v Kliničnem centru, od leta 2001 opravlja dela asistentke pri predmetu Zdravstvena vzgoja na Visoki šoli za zdravstvo Univerze v Ljubljani. Je vodja raziskovalne skupine Društva medicinskih sester in zdravstvenih tehnikov Ljubljana in raziskovalno deluje na področjih ugotavljanja značilnosti poklicne skupine medicinskih sester, etike $v$ zdravstveni negi, medosebnih odnosov $v$ zdravstvu ter učinkovitosti in kakovosti izvajanja zdravstvene vzgoje. 


\section{SUMMARY}

\section{Change of Relations in Health Care as a Precondition for a Successful Health Reform}

There is a strong hierarchy of relations among professional groups in health care. Among the so-called "physician subordinated professions" there are entire professional groups that are left out of the decision-making processes but could, with their respective expertise, provide better quality of health care service. Success and efficiency of the system could be substantially improved by a higher rate of inclusion of all of the participants in all phases of work, which would be better use of available human resources. In order to achieve this, some crucial changes of the prevailing relations in the Slovene health care system would need to occur.

Over the last two hundred years, medical associations have managed to secure a special status and a privileged position in society because of their profession. The article firstly presents historical sources of physicians' power, which is undoubtedly based on the characteristics of their work and their professional field. This power helps medical associations shape health care systems according to their needs and at the same time strongly affects the model of health that prevails in a society. The medical profession prefers the biomedical model of health, which is limited to the chemical processes within the body and bestows absolute power in the hands of those who have this kind of expert knowledge (physicians). This model does not allow equal relations among other health care professions. In contrast, the bio-psycho-social model of health/health care, by including a much wider specter of various health factors that cannot be controlled exclusively by a single professional group, also makes room for other professional groups. Certain traditional responsibilities of physicians should be transferred to other professional groups in health care. The sooner this process begins and the higher the number of the professional fields that it encompasses, the sooner the physicians' ability to enlarge their privileges and improve their relative position among professional groups within and outside health care will decrease.

The reform of the health care system proposed by the Ministry of Health of the Republic of Slovenia made the first step in this process by posing the idea of creating multi-professional teams. The next step can be achieved by increasing the self-confidence of the non-physician professional groups participating in health teams. The central role belongs to nurses, who are the largest professional group in health care. Acknowledging nursing care as an integral part of health care and nurses as equal members of health 
Seljak, Kvas

Spremembe odnosov v zdravstvenem varstvu

teams could be an important step towards a different understanding of health and health care. This could be achieved by establishing a strong nursing professional group that would, on the basis of its professional knowledge, be able to assert its contribution to patients' health. Following this idea, it is necessary to develop education programs for nurses comparable to those for physicians. It is necessary to accelerate the implementation of university level programs and to start preparing master's and doctor's degree programs in nursing as soon as possible. Besides, physicians should be educated on the management of multi-professional teams. Presently, physicians in their management of medical treatment use methods that are typically used in the processes involving relatively low qualified human resources: promoting order and discipline within clearly set hierarchy of different professions. In contrast the new health teams demand skills of a different kind: to coordinate highly educated experts of different professions, to motivate them and to encourage their creativity. To lead such a team in a qualitative way that would contribute to the improvement of health care, physicians would need to obtain skills, which they do not yet have. 